\title{
Birth and Growth of Semiotics
}

\author{
Zinah Abbass Dweich, Iman M. M. Muwafaq Al Ghabra \\ University of Baghdad, College of Education for Women, Baghdad, Iraq
}

DOI: $10.37648 / \mathrm{ijrssh.v10i04.024}$

Received:15 $5^{\text {th }}$ October, 2020; Accepted:20 $0^{\text {th }}$ November, 2020; Published: $24^{\text {th }}$ November, 2020

\begin{abstract}
The existence of signs whether natural or unnatural in the ordinary life has forced scholars to think about and study them seriously. The aim of the current review paper is to develop an understanding of semiotics, highlight its birth and growth, and introduce the different stages of its development depending on data collected from previous studies. Many of literate people consider semiotics, the study of signs, vague because it does not have enough attention from academics in spite of its important role in the process of communication, and the interpretation of the different activities among people as well as the different natural signs occurring around them. It appeared that the ancient people felt the necessity to found such science because they were using signs before the usage of writing. The prime need of people at the age of antiquity was to know the divine and medical instructions; there were men specialized in interpreting signs in that respect since then.
\end{abstract}

Keywords: Semiotic Birth, Semiotic Development, Semiotic Growth, Semioticians, Semiotics

\section{INTRODUCTION}

People often use signs intentionally and unintentionally, and they continuously face human and non-human signs in their daily life. They often express those signs according to their inherited knowledge. The existence of signs whether natural or unnatural in the ordinary life has forced scholars to think about and study them seriously. Many of literate people consider semiotics, the study of signs, vague because it does not get enough attention from academics in spite of its important role; it is as important as linguistics for the process of communication. Jorna and Wezel (1995) state that "Semiotics as the study of sign systems and sign use is inadequate. Concepts that might give grip on the feeling of directness and engagement relate to attuning and resonance, but how this relates to semiotics is unclear". The aim of the current review paper is to develop an understanding of semiotics, highlight its birth and growth, and introduce the different stages of its development through history depending on data collected from previous research.

\section{LITERATURE REVIEW}

\section{A. Concerning identification}

Semiotics is known as the study of signs which are either linguistic or non-linguistic. Schramm and Porter (1982) define signs as: "they are the elements in communication that can be decoded into "meaning'." According to De Sauusure, Bally \& Sechehaye (1915) identified the term "semiology" and its role before its being a science as it studies the signs of the social life. Similarly, Hlynka (1991) states that semiotics is often divided into three parts: First, syntactics whose focus is on the work structure; second, semantics whose focus covers the work textual meaning as well as visual literacy concepts; third, pragmatics which describes the work through connecting the antecedents with consequences.

Chandler (1994) states that De Saussure, who adopted structuralism has founded for the modern semiotics in his book (Course in General Linguistics, 1915), and considers Peirce among the key figures in the field. The concern of structuralism was in the analysis of sign system organization as "language" 
depending on the surface features. Then later, Morris came to develop the behaviorist semiotics concerning in deep features. Now, the move is towards society to the social semiotics. Eco (1976) declared the general semiotic theory saying that:

A general semiotic theory will be considered powerful according to its capacity for offering an appropriate formal definition for every sort of sign-function, whether it has already been described and coded or not. So the typology of modes of sign-production aims at proposing categories able to describe even those as yet uncoded sign-functions conventionally posited in the very moment in which they appear for the first time.

\section{B. Concerning the birth and stages of growth}

Semiotics was born since the birth of the need to recognize the language of signs in the ancient ages. It passed through a series of different theories and types of interpretation. However, along with its growth, there has been no parallel focus.

A big difference is between the old concept of semiotics at its birth when the main concern was in signs respecting divination and medicine, and the modern concept whose main concern is in linguistic and non-linguistic signs in general as Manetti (2010) mentions. Thus, it is beneficial to follow its evolution starting from its birth.

- The Age of Antiquity; the Ancient Era (3000-476) B.C.: Manetti (2010) refers to Mesopotamian antiquities of ancient civilizations, which showed that they had used signs mainly to express the divine language. Signs were so important for the Mesopotamian culture to transfer information from God to people. They were also the language of medicine; for this reason, there were people who devoted themselves to writing signs. In this respect, Manetti says: "We can first find a foregrounded use of signs in Mesopotamian divinatory tablets from the third millennium B.C.E." Annus (2010,) confirms this stating: "the first written evidence for a concept of sign, however, comes from cuneiform texts of Ancient Mesopotamia." Practices of semiotics emerged from that old age through divination, medicine, philosophy and history giving signs distinctive and individual concept. Allen (2010) refers to the same point saying: "If in this area as in so many others the Romans were indebted to the Greeks, here as elsewhere the Hellenic world was indebted to the ancient Near Eastern civilizations that preceded and coincided with it."

- The Age of the Greek (800-146) B.C.: It was the age of the great researchers and philosophers who had impacted the culture of linguistic and non-linguistic communication. Oehler (1987) states that the term "semiotics" was used for the theory of signs, and many of the related words used today had their origins in Greek. The theory of signs had first originated in the sixth century before Christ. Pre-Socratic, Sophist, and Plato discussions revealed the existence of semiotic investigations related to the nature of language and communication, and the relation of sign to the signified. The following philosophers are some of this great age:

- Thales of Miletus: Danesi (2010a) refers to Thales of Miletus as the first philosopher who had historical record from the period around 580 B.C. Thales who was interested in astronomy, physics, and meteorology phenomena could initiate the step away from mythology towards the interpretation of science and natural phenomena. He was the founder of the western philosophical method established after centuries.

- Plato: Manetti (2010) states that there was no separation between the theory of sign, and theory of language in Plato as many others of him. There were also semiotic features showing the existence of linguistic signs and terms in his dialogues, such as "semeion" referring to different domains especially in his book "Cratylus" on nouns.

- Cratylus: Keller (2000) attracts the attention to the dialogues between the two ancient Greek philosophers Cratylus and Hermogenes. Cratylus's theory was "naturalism"; he asserted the thought of etemology which was refuted by Plato.

- Hermogenes: Keller (2000) also refers to the theory of Hermogenes which was "conventionalism"; this means all names people give to others or to things are correct. To this respect, he gave the following example: if someone gives the name "horse" to a man, then after some time it will be correct; "man" as a public name, and "horse" as a private name. Hermogene's theory got a lot of criticism, and critics called it "untenable". 
- Socrates: Among the prominent philosophers of that era, Socrates who was born in $469 \mathrm{BC}$ as it is mentioned in Danesi (2010a). Danesi also mentions that Socrates identifies the philosopher's task as to move people to thinking by themselves; Socrates was the first who believed that knowledge was innate rather than acquired; his way of philosophy has had its effect on modern philosophy up to now. Before Danesi, Keller (2000) refers to Socrates' dialogue with Hermogenes, and states that there was some reference to a prescriptive theory of naming. In order to make sure of the correct nouns, Socrates was strict to produce etymologies. Keller shows Plato's disapproval of Socrates' long dispute with Cratylus about "the correctness of nouns" with no settlement.

- Aristotle: Oehler (1987) mentions that the majority of semiotic terms used nowadays have originated from the Greek. Aristotle developed and described the semiotic system he has first founded exploring the concept of symbol to include in it. Seung (1989) illustrates Aristotle's ten categories which are: substance, quantity, quality, relation, place, time, position, state, action, and affection; these categories were the fundamentals of the traditional view of proposition. Modrak (2001) cites Aristotle's:

Spoken words then are symbols of affections of the soul, and written words are symbols of spoken words. And just as written letters are not the same for all humans, neither are spoken words. But what these primarily are signs of, the affections of the soul, are the same for all, as also are those things of which our affections are likenesses.

The quotation clearly pinpoints the usage of symbols in Aristotle's interpretation of meaning.

Manetti (2010) refers to the period between (384_322BCE), and confirms that Aristotle's theory have had its great effect on the history of forming thought concerning semiotics. The idea of separating the theory of sign "referring to non-verbal signs" from the theory of language was an essential factor of his work, and it has earned the concern of contemporary scholars. Aristotle located the theory of signs at a point between rhetoric and logic depending on epistemology and ontology giving an example to show that to know a woman has milk in her breasts is to know that she has given birth.
- The Stoics: Manetti (2010) attracts the attention to this time showing the existence of the roots of semiotico-linguistic theory of language which was centered on ontology "nature of being". Baltzly (2019) points out to the stoics who included the philosophy of language and epistemology "theory of knowledge" in logic. The innovation they did was the theory of "sayables" in which they distinguished between utterances "the signifier", name bearers things "the signified", and signification which is the "sayable" that is related to the mind.

The Age of Augustine (395-430) C.E.: Danesi (2010) reports that Augustine was the first philosopher who formulated the theory of sign as a relational construct $(\mathrm{X}=\mathrm{Y})$. This is confirmed by Tornau (2019) who introduces Augustine as the greatest philosopher of his age, the ancient era, that he played a prominent role in the field of semiotics. Then, Tornau (2019) declares that Augustine followed the Stoics in the distinction between the sound of a word, its meaning, and the signified thing; thus, he sorted the world into things and signs. Next, he classified signs into "natural" which are spontaneously occur, and "given" which refers to language; in this respect, Augustine gave an example of "smoke to signify fire". In addition, he interpreted the language as a system of given signs to signify things, thoughts, and emotions; all have been taken from the scripture. Connaghan (2004) and Manetti (2010) refer to Augustine's classification of signs as follows:

Signa Naturalia: People are able to know this type without the need for interference, such as the sight of smoke refers to the existence of fire; animal tracks, and facial expressions are more examples of unintentional signs from which people can infer meaning according to causal relationship;

Signa Data: Augustine referred to the motion of spirits effected by Scriptural data as intentional; people show their thoughts and feelings to each other by linguistic signs "words". He also placed animals' sound in this type of signs since it is intentional; animals produce sound in order to tell about the existence of food.

Manetti (2010) sees that Augustine was different from the Stoics in the following items:

- Uniting the nonverbal signs with spoken expressions in one category; 
- Identifying the linguistic expression as a word covering both of the signifier and the signified, and in their turn signify something else while the Stoic considered only words as signifiers and things as signified;

- Augustine's theory of linguistic sign had psychological and communicative nature that the speakers transfer the signified which is in their minds to the listeners' minds; the Stoics' focus of their theory of language was on signification.

Markus (1957) stated that Augustine's theory of signs was designed from the beginning to mean the theory of language as well as the other kinds of sign. Augustine's first discussion was on the meaning of signs in which, he focused on words as the most important kind of sign. His opening question was "Why do we use signs?", and the answer was that the aim of speaking is "either to teach or to remind others or ourselves". In the same reference, Augustine explained, in his theory, the meaning of signs by:

- other signs - synonyms;

- circumlocution - using phrases to explain the meaning;

- pointing or gesturing;

- representing by pictures.

The Age of the Scholasticism (1100 - 1700): Danesi (2010a) declares that Augustine's views went unnoticed until this age, the age of Arabic scholars who were interested in translation. The focus of Arabic scholars' translation was on the works of Plato, Aristotle, and the great Greek thinkers. Oehler (1987) states that scholastics continued studies on the problems of semiotics along the middle ages until the 17th and 18th centuries, the appearance of semiotic contributions by philosophers such as Locke.

John Locke (1632-1704): Short (2007) says that Locke used the word "semiotics" in his essay in 1690 as a name for "doctrine of signs" which was some kind of logic. Locke included words and ideas in signs saying that words are "signs of ideas" because they convey ideas.

The Age of Enlightenment (1715-1789): Mogashoa (n. d.) states that this age is marked by Kant who was one of the most influential scholars of his age. Kant, as Mogashoa states, described his age as the age of "Enlightenment", but not the "Enlightened"; this is because, as he declared, the majority of the public were still under tutelage.

Immanule Kant/ German (1724-1804): In order to know the different types of categories of things in the world, Kant, as Higuera (n. d.) states, formed the following question "What are the things that are given when cognizing anything?" Seung (1989) states that Kant had not seen Aristotle's categorization systematic; yet, he got to benefit from it, and added more elements to be as the following four groups:

- Quantity: unity, plurality, totality;

- Quality: reality, negation, limitation;

- Relation: inherence and subsistence, causality and dependence, community;

- Modality: possibility-impossibility, existencenonexistence, necessity-contingency.

Hence; these twelve categories built from logic help people to have better information for things through relations.

The Modern Age- Structuralism (1914-1945): For this period of time, it is important to mention Pierce together with Saussure as they were pioneers of their age. Living in two different countries, each one of them differently wrote about language and signs. Yakin and Totu (2014) refer to their big contributions towards modern semiotics. They also state that their approaches have become as a multidisciplinary basis because they have impacted fields and disciplines other than philosophy and linguistics. The fault of this age philosophers Posner (2011) states is the rejection of the traditional thoughts; this reason was behind the demise of structuralism soon. After the Second World War, skepticism grew within humanities and social sciences, and had its effects on semiotic culture.

Charles Sanders Peirce/ American (1839 - 1914): Feibleman (1945), showed how Pierce had considered Kant in particular and the German philosophy in general rich of knowledge. Yet, his studies drifted apart from Kant's philosophy which was of little weight according to Peirce though Henault, (2010) refers to him as he was the father of semiotics stating that he upgraded a philosophical system identical to the classical systems among which is Kant's.

Short (2007) states that Peirce was unlike Kant in the interpretation of "representation"; Kant focused only on the mental content in his writings while the focus of Peirce was on the mental content and other things to interpret "representation". Then later, Short states that Peirce interpreted signs by his triadic 
relations which were sign -> object \& interpretant in which he once used sign as a mediator between object and interpretant, and the other time, he used the interpretant as a mediator between sign and object.

According to Houser, (2010) Pierce, who was one of the best logicians of his age, was convinced that there should be classifications and norms within the mission aspects of logic: representation, inference, and argument displaying detailed reasons to show why Pierce had seen semiotics as a normative science. Houser explains Peirce's claim that logic gets to benefit from mathematics borrowing formal structures and relational models to represent relations for logical analysis using signs and sign-operations.

Ferdinand de Saussure/ Swiss (1857 - 1913): Yakin and Totu (2014) refer to De Saussure as the founder of modern linguistics showing that he had proposed the term "semiology" to be the science of signs' life studies recognized through the social psychology; this is mentioned in Saussure's collected lectures. In 1915, Saussure's collected lectures were published in a book that had a strong impact on the modern linguistics. In his lectures, Saussure explained that "semiology" referred to the constitution of signs, and elements governing them. According to him, linguistics, psychology, and society are parts of semiology as a general science. In the same reference, Saussure said that the linguistic sign connects a sound-image and a concept - not a name and a thing. He could not use the word "symbol" to assign the linguistic sign linking between the "signifier" and the "signified" because symbols are not completely arbitrary; they are not empty that they have fundamentals. For example, a pair of scales is a symbol for "justice"; the feature of the symbol is not arbitrary; one cannot substitute it with a chariot.

Henault, (2010) explains Saussure's thought of "Man is a born semiotician" as that Man:

- cannot live without expressing and using signs;

- is able to create different kinds of signs which could be expressive, but using the verbal language is the most expressive;

- intends to construct a science of all languages which is "semiotics" to have advantage of using it.

Roman Jakobsen (1896 - 1982) Russian: Winner (1987) pointed out that Jakobson never saw any boundaries among linguistics, poetics, and semiotics; for him, they were his main and favorite interest; he considered them one collection; each one was closely connected to the other. He constructed poetic aesthetics theories to be the foundation of aesthetic semiotics later on. Among his contributions to semiotics are aesthetic and non-aesthetic messages, verbal and visual signs, how art works signify, how they are encoded and decoded, and the rejection of De Saussure's rigorous dichotomies langue/parole, and synchrony/ diachrony. He went to America and became acquainted with the work of Peirce, so he is considered structural. He used his taxonomy of signs to moderate De Saussure's view of arbitrariness of the verbal sign.

The Postmodern Age: Posner (2011) states that adversaries of the modern age philosophers gathered and labeled themselves postmodernists or poststructuralists. They began to collect what the previous ages achieved with the remains of structuralism and uncompleted achievements.

- Charles Morris (1901 - 1979) American: Fan (2006) clarifies Morris's point of view to understand the communicative feature of a sign stating that a sign is similar to a sign vehicle which comprises designatum, and interpreter; according to Morris the triadic relation, he explores three dimensions of semiotics that are syntactics, semantics, and pragmatics. In order to comprehend the communicative nature of the sign, one must analyze and identify the relations to other signs, denotation, and interpreters. In this respect, Morris's viewpoint is that semantics studies the sign and object relations; syntactics studies the sign relations; pragmatics studies the sign and interpreter relations.

- Roland Barthes (1915 - 1980) French: The editors of Encyclopedia Britannica (2020) state that Roland Barthes was mostly effected by Saussure; Barthes was a French essayist and critic. His first book was about the examination of arbitrariness of language structure. His theories were influential in Europe and U.S.A. during the late of 1970s. Danesi (2010b) thinks that Barthes was the first who applied the semiotic theory to media and culture in his book "mythology" published in 1957. Barthes (1972) declared that the process of explaining mythologies accurately must go through form, ideology, and history altogether as one unit. Barthes (1964) stated that signifiers such as objects, images and styles of 
behavior never signify without the aid of linguistics; hence, visual items are preferred to be duplicated by linguistic messages to confirm their meaning. Yet, in this case, a part of the semiological "iconic" message would be redundant because in spite of the spread of graphic illustration, the written language would be more desirable; none could understand the signifieds without the designation of language.

Barthes (1964, p. 3) referred to that semiology is a part of linguistics. Then, he borrowed four headings from structural linguistics to group the elements of semiology mentioned below, and pointed out that if this categorization were known well, they would be rich sources to what he called the field of intellectual imagination:

I. Language and speech;

II. Signified and signifier;

III. Syntagm and system;

IV. Denotation and connotation.

- Umberto Eco (1932 - 2016) Italian: Concerning metaphor, Eco (1986) states that it is produced and interpreted according to the sociocultural format, which specifies its semiotic identity, and differences of properties. Concerning the symbol, Eco in the same reference states that it is not a mere sign with unknown qualities, nor is it a certain form of sign production; the symbol is a textual style that helps in the production, and interpretation of the features of the text.

\section{CONCLUSION}

Investigating the literature review concerning the birth of semiotics has shown that the focus, in the beginning, was on transferring the divine instructions. Logically speaking, this is so true because messengers of Allah came with so many signs to let people feel His wisdom and strength, and understand His instructions. Along history, great philosophers did hard work on it some ages, and they overlooked it in other ages. Since semiotics studies the linguistic and non-linguistic communication, it is necessary to consider it:

- the general field, and linguistics is one of its parts;

- one of the essential requirements for studying languages.

Research has shown that the study of sign is part and parcel of the study of the different fields of language.

\section{REFERENCES}

Allen, James (2010) Greek Philosophy and Signs in Annus, Amar ed. (2010) Divination and Interpretation of Signs in the Ancient World, the University of Chicago, Oriental Institute Seminars, No. 6, Retrieved March 31, 2020, from https://oi.uchicago.edu/sites/oi.uchicago.edu/files/uploads/shared/docs/ois6.pdf

Annus, Amar ed. (2010) Divination and Interpretation of Signs in the Ancient World, the University of Chicago, Oriental Institute Seminars, No. 6, Retrieved March 31, 2020,from https://oi.uchicago.edu/sites/oi.uchicago.edu/files/uploads/shared/docs/ois6.pdf

Baltzly, Dirk (2019) "Stoicism". In Zalta E. N. (ed.), the Stanford Encyclopedia of Philosophy (Spring Edition). Stanford University. Retrieved February 26, 2020 from https://plato.stanford.edu/archives/spr2019/entries/stoicism/

Bally, Charles, \& Sechehaye, Albert (Eds.). (1915). Course in General Linguistics: Ferdinand de Saussure. McGraw-Hill Book Company.

Barthes, Roland (1972) Mythologies, (A Lavers Trans.). New York: Jonathan Cape, Ltd. (Original work published 1957). Retrieved March 3, 2020 from https://soundenvironments.files.wordpress.com/2011/11/roland-barthes-mythologies.pdf

Barthes, Roland (1964) Elements of Semiology, publ. Hill and Wang, Retrieved March 3, 2020 from: https://www.marxists.org/reference/subject/philosophy/works/fr/barthes.htm

Chandler, Daniel. (1994). Semiotics for Beginners. Retrieved October 17, 2020. http://www.aber.ac.uk/media/Documents/S4B/

Connaghan, Charles (2004). Signs, Language, and Knowledge in St. Augustine's Demagistro, University College London, Ph. D. in Classics.

Danesi, Marcel (2010a). The History of Philosophy as Semiotic Process: A note on John Deely's monumental Four ages of understanding, Semiotica 178-1/4 (2010), 23-37, DOI 10.1515/semi.2010.003 
Danesi, Marcel (2010b). Semiotics of Media and Culture in Cobley, Paul (ed.) The Routledge Companion to Semiotics, London and New York, Routledge Taylor and Francis Group

Eco, Umberto. (1986). Semiotics and the Philosophy of Language, U.S.A., Midland Book Edition.

Eco, Umberto. (1976). A Theory of Semiotics.

The Editors of Encyclopaedia Britannica. (November 8, 2020). Roland Barthes. Encyclopaedia Britannica. Retrieved November 10, 2020 from https://www.britannica.com/biography/Roland-Gerard-Barthes

Fan, Jiang-Ping (2006) Charles Morris's Semiotic Model and Analytical Studies of Visual and Verbal Representations in Technical Communication, J. Technical Writing and Communication, Vol. 36(2), 121-139.

Feibleman, James. (1945). Perice's Use of Kant. The Journal of Philosophy. Vol. 42, No. 14.(July 5, 1945), pp. 365-377. DOI: $10.2307 / 2019193$

Henault, Anne (2010) The Saussurean Heritage, in Cobley, Paul (ed.) The Routledge Companion to Semiotics, London and New York, Routledge Taylor and Francis Group https://books.google.iq/books?id=iduOAgAAQBAJ\&pg=PA105\&lpg=PA105\&dq=\%22Man+is+a+born+semiotici an\%22\&source $=$ bl\&ots $=q V y n M 80 d 6 M \& s i g=A C f U 3 U 0 g c T C ~ h W C 82 s V T h N 01 L L Z N 16 y E r A \& h l=e n \& s a=X \& v e d$ =2ahUKEwjiyqK068vsAhVrs4sKHdbXB3wQ6AEwAXoECAEQAg\#v=onepage \&q=\%22Man\%20is\%20a\%20bor n\%20semiotician\%22\&f=false

Higuera, Claudio Julio Rodr'1guez (n. d.) A Brief Introduction to Peirce in Biosemiotics, Department of Semiotics, University of Tartu

Hlynka, Denis. (1991). Applying Semiotic Theory to Educational Technology. In Denis Hlynka \& John C Belland (eds.) Paradigms Regained: The Uses of Illuminative, Semiotic and Post-modern Criticism as Modes of Inquiry in Educational Technology (pp. 37-50). Educational Technology Publications, Inc. https://books.google.iq/books?hl=en\&lr=\&id=9JDsxcJOUA4C\&oi=fnd\&pg=PR5\&dq=modern+semiotic+theory\& ots=Ni5viOlwqY\&sig=kcssix6b6hQC5iLd_5r2LACFW1Y\&redir_esc=y\#v=onepage \&q=modern $\% 20$ semiotic $\% 20$ theory \&f=false

Houser, Nathan (2010) Peirce, Phenomenology and Semiotics, in Cobley, Paul (ed.) The Routledge Companion to Semiotics, London and New York, Routledge Taylor and Francis Group

Jorna, R. J., \& Wezel, W. V. (1995). Worldmaking with objects: a case in semiotic engineering, University of Groningen, Retrieved September 30, 2020 from https://www.rug.nl/research/portal/files/3281475/95A12.pdf

The Journal of Philosophy. (1945). https://www.jstor.org/stable/2019193?seq=1

Keller, Simon (2000) An Interpretation of Plato's Cratylus, Phronesis, XLVI4, koninklijke Brill, PP. 284-305, https://doi.org/10.1163/156852800510234

Manetti, Giovanni (2010) Ancient Semiotics in Cobley, Paul (ed.) The Routledge Companion to Semiotics, London and New York, Routledge Taylor and Francis Group

Markus, R. (1957). St. Augustine on Signs. Phronesis, 2(1), 60-83. Retrieved March 31, 2020, from www.jstor.org/stable/4181613

Modrak, Deborah K. (2001) Aristotle's Theory of Language and Meaning, University of Rochester, Cambridge University Press

Mogashoa, Humphrey. (n. d.). The "Age of Enlightenment" is not the "Enlightened Age":

Revisiting Kant's (1724-1804). Argument on the Enlightenment. University of South Africa. Retrieved October 29, 2020 from http://www.scielo.org.za/pdf/she/v35n1/01.pdf

Oehler, Klaus (1987) An Outline of Peirce's Semiotics, in Krampen, Martin et al., Topics in Contemporary Semiotics: Classics of Semiotics, New York, Plenum Press.

Posner, R. (2011). Post-modernism, post-structuralism, post-semiotics? Sign theory at the fin de siècle, Semiotica 183-1/4 (2011), 9-30, DOI 10.1515/semi.2011.002

Schramm, Wilbur, and Porter William E. (1982) Men, Women, Messages, and Media: Understanding Human Communication, Harper \& Row, Publishers, Inc., New York, U. S. A.

Seung, T. K. (1989). Kant's Conception of the Categories. The review of metaphysics Vol. 43, No. 1. Retrieved October 22, 2020 https://www.jstor.org/stable/20128836?seq=2\#metadata_info_tab_contents 
Short, T. L. (2007). Peirce's Theory of Signs. Cambridge University Press.

Tornau, Christian, (2019). "Saint Augustine". In Zalta E. N. (ed.) The Stanford Encyclopedia of Philosophy (Winter Edition), Stanford University. Retrieved February 26, 2020. https://plato.stanford.edu/archives/win2019/entries/augustine/

Winner, Thomas G. (1987). The Aesthetic Semiotics of Roman Jakobson in Pomorska, Krystyna; Chodakowska, Elzbieta; McLean, Hugh; Vine, Brent (eds.). Language, Poetry and Poetics: The Generation of the 1890s: Jakobson, Trubetzkoy, Majakovskij. Proceedings of the First Roman Jakobson Colloquium, at the Massachusetts Institute of Technology, October 5-6, 1984, Germany, Mouton de Gruyter. Retrieved March 5, 2020 from https://books.google.iq/books?id=UY3yCQAAQBAJ\&printsec=frontcover\&source=gbs_ge_summary $r \& c a d=0 \# v$ =onepage\&q\&f=false

Yakin, Halina Sendera Mohd. \& Totu, Andreas (2014) The Semiotic Perspectives of Peirce and Saussure: A Brief Comparative Study, The International Conference on Communication and Media 18-20 October 2014, Procedia Social and Behavioral Sciences 155 ( 2014 ) 4 - 8, Langkawi, Malaysia, Retrieved on $3^{\text {rd }}$ March, 2020 from: http://repo.uum.edu.my/12976/1/1-s2.0.pdf 